\title{
The increase of rainfall erosivity and initial soil erosion processes due to rainfall acidification
}

Ataollah Kavian ${ }^{* 1}$, Aazam Alipour ${ }^{1}$, Karim Soleimani ${ }^{1}$, Leila Gholami ${ }^{1}$, Pete Smith $^{2}$, Jesús Rodrigo-Comino ${ }^{3}$

1 Department of Watershed Management, Faculty of Natural Resources, Sari Agricultural Sciences and Natural Resources University, Sari, Iran, corresponding author. a.kavian@sanru.ac.ir; aalipuor@yahoo.com; solaimani2001@yahoo.com; 1.gholami@sanru.ac.ir

2 Institute of Biological and Environmental Sciences, School of Biological Sciences, University of Aberdeen, 23 St Machar Drive, Room G45 Aberdeen, AB24 3UU, Scotland, UK. pete.smith@abdn.ac.uk

3 Instituto de Geomorfología y Suelos, Department of Geography, Málaga University, Campus of Teatinos s/n, 29071 Málaga, Spain. rodrigo-comino@uma.es

\section{Abstract}

The drastic growth of population in highly industrialized urban areas, as well as fossil fuel use, are increasing levels of airborne pollutants and enhancing acid rain. In rapidly developing countries such as Iran, the occurrence of acid rain has also increased. Acid rain is a driving factor of soil erosion due to the destructive effects on biota and aggregate stability; however, little is known about its impact on specific rates of erosion at the pedon scale. Thus, the present study aimed to investigate the effect of acid rain at $\mathrm{pH}$ levels of 5.25, 4.25 and 3.75 for rainfall intensities of 40 , 60 and $80 \mathrm{~mm} \mathrm{~h}^{-1}$ on initial soil erosion processes under dry and saturated soil conditions using rainfall simulations. The results were compared using a two-way ANOVA and Duncan tests and showed that initial soil erosion rates with acidic rain and non-acidic rain under dry soil conditions were significantly different. The highest levels of soil particle loss due to splash effects in all rainfall intensities were observed with the most acidic rain $(\mathrm{pH}=3.75)$, reaching maximum values of $16 \mathrm{~g} \mathrm{~m}^{-2} \mathrm{~min}^{-1}$. The lowest levels of particle losses were observed in the control plot where nonacidic rain was used, with values ranging from 3.8 to $8.1 \mathrm{~g} \mathrm{~m}^{-2} \mathrm{~min}^{-1}$. Similarly, under saturated soil conditions, the lowest level of soil particle loss was observed in the control plot and the highest peaks of soil loss was observed for the most acidic rains $(\mathrm{pH}=3.75$ and $\mathrm{pH}=4.25)$, reaching 
31 maximum average values of $40 \mathrm{~g} \mathrm{~m}^{-2} \mathrm{~min}^{-1}$. However, for saturated soils with acidic water, but

32 with non-acidic rain, the highest soil particle loss was observed for the control plot for all the

33 rainfall intensities. In conclusion, acidic rain has a negative impact on soils, which can be more

34 intense with a concomitant increase in rainfall intensity. Rapid solutions, therefore, need to be

35 found to reduce emission of pollutants into the air, otherwise, rainfall erosivity may drastically

36 increase.

37 Keywords: acid rain; splash erosion; runoff; soil loss

\section{Introduction}

40 The increasing use of fossil fuels in industry, manufacture and transport, especially in rapidly

41 developing countries such as Iran, is emitting a large quantity of pollutants into the atmosphere

42 and causing damage to human health and to ecosystems (Ashtari et al., 2018; Bahrami Asl et al.,

43 2018; Mohammadiha et al., 2018). Moreover, due to the rapid growth of urbanization and the

44 concentration of population close to industrial areas such as Tehran, Isfahan, Arak, Ahvaz and

45 Mashhad, the development of old and worn transportation vehicles, factories, and power plants

46 that use fossil fuels, air pollution has increased (Fanni, 2006; Hafeznia et al., 2017; Yousefi et al.,

47 2017). However, in polluted cities in developing countries, Atash (2007) highlighted that the

48 implementation of 10-year strategic plans has been delayed. In recent years, air pollution rates

49 have exceeded dangerous levels which forced the authorities to enforce traffic constraints and

50 school closures. In a study performed by Lelieveld et al. (2015), Tehran was ranked among the

51 cities with a high mortality rate due to human exposure to long-term air pollution. According to

52 Shahbazi et al. (2016), annual pollution from fixed sources such as factories, and mobile industries 
53 including the transportation agency in Tehran for 2013, amounted to $37.4 \mathrm{~kg}, 85.5,506.7,83.6$ and

$548.5 \mathrm{~kg}$ for $\mathrm{SO}_{\mathrm{x}}, \mathrm{NO}_{\mathrm{x}}, \mathrm{CO}, \mathrm{VOCs}$ and PM emissions, respectively. Also, Alizadeh Choobari et al.

55 (2016) investigated $\mathrm{PM}_{10}$ and $\mathrm{PM}_{2.5}$ levels in the north of Tehran, which were found to be

56 significantly higher than the national average on a per $\mathrm{m}^{2}$ basis. The excessive emission of

57 pollutants and acidifying compounds such as nitrous oxides and sulphuric acid into the atmosphere

58 favours conditions for acid rain in the form of fog, snow and rain (Uchiyama et al., 2017; Zheng and $\mathrm{Yu}$ Hong, 1994). Acid rain is defined as a rain characterized by $\mathrm{pH}$ values lower than 5.6 (Mirhosseini et al., 2009; Purohit, and Kakrani, 2002; Neill, 1993; Welburn, 1990). Acid rain 61 adversely affects ecological and environmental processes (Wang et al., 2018; Wei et al., 2017).

62 Over the last 50 years, several researchers have highlighted the negative environmental impacts of 63 acid rain, including destruction of buildings and tools (Yokom and Beer, 1983), forest and 64 geological formation degradation (Ulrich, 1980, Driscoll et al., 2001), and adverse effects on crops 65 and soil fertility (Ferenbaugh, 1976; Pell et al., 1987; Irving, 1987).

66 Evidence is gathering that this acid rain is increasing close to highly populated and industrial areas 67 in Iran. For example, Moarref et al. (2011) recorded $\mathrm{pH}$ values of about 2.4 by evaluating the 68 chemical composition of rain in Ahwaz city. Mirhosseini et al. (2009) investigated the occurrence 69 of acid rain in Sarcheshmeh area, located in the Kerman province, and determined that that 70 occurrence is an inevitable phenomenon close to highly industrial and populated regions. 71 However, these authors remarked that there is a lack of quantification of the effects of acid rain on 72 soil processes such as water soil erosion (Mirhosseini et al., 2009; Moarref et al., 2011). As acid 73 rain impairs soil fertility and vegetation development, the areas with bare soil surfaces will increase 74 (Driscoll et al., 2001). Lack of vegetation is one of the most important driving factors of soil 75 erosion processes in watersheds and hillslopes (Cerdà et al., 2018; Saleh et al., 2017; Parsakhoo et 
76 al., 2012a). Water soil erosion is initiated by the collision of rain drops with the soil surface

77 (Ellison, 1944; Ellison, 1947; Free 1952). Rain drops can separate and move soil particles and

78 aggregates (Fernández-Raga et al., 2017; Marzen et al., 2015).

79 The splash effect on soils is the first stage in the erosion process, which is the result of 80 bombardment of the soil surface by rain droplets (Qinjuan et al., 2008, Wuddivira et al., 2009).

81 The splash effect, by crushing soil particles and reducing their diameter, leads to a reduction of 82 soil particle resistance against transport, and also a decrease in water penetration in soil surface 83 layers, which in turn can increase runoff, erosion and sediment transport (Barry et al., 2010; 84 Sadeghi et al., 2017).

85 However, there is a lack of information about the degree of disintegration of soil aggregates due 86 to splash erosion at different levels of rain acidity (Xu et al., 2002; Manahan, 2005). A number of 87 negative effects of acid rain and soil erosion can occur, such as leaching of nutrient cations, release 88 the toxic elements and soil acidification (Mirhosseini et al., 2009). Also, the sedimentation of the 89 elements in the form of insoluble hydroxides and carbonates and organic complexes can increase. 90 Moreover, when soil acidification occurs, heavy metals such as zinc and cadmium are mobilized, 91 potentially leading to toxic concentrations (Smith, 1994).

92 Analysis of initial soil erosion processes in combination with acid rain is time-consuming and the 93 intra-plot variation is high. Therefore, one of the most direct measurement methods of initial soil 94 erosion, where rainfall conditions can be controlled, is the rainfall simulator (Iserloh et al., 2013), 95 which has been widely used in Iran (Parsakhoo et al. 2012b; Kavian et al. 2014; Safari et al. 2016; 96 Sadeghi et al., 2017; Ayoubi et al., 2018).

97 The main aim of this study was to assess the impact of acidic rain at different $\mathrm{pH}$ levels and 98 intensities on initial soil erosion processes under distinct soil conditions using a small portable 
99 rainfall simulator. The experiments were conducted under laboratory conditions to avoid any

100 external factors such as wind, soil property changes or inclinations. We hypothesize that this first

101 approach will allow us to show if acidic rain per se directly affects initial soil erosion processes,

102 as a basis for future research under natural conditions and in different environments.

\section{2. Materials and methods}

104

\subsection{Soil sampling}

105 The altitudinal range of the case study region is between 150 and $300 \mathrm{~m}$ above sea level with a 106 mean annual precipitation of $600 \mathrm{~mm}$. Most events occurs are during the winter and spring seasons

107 (November-May), with a means annual temperature of $18.5^{\circ} \mathrm{C}$. Two hundred and fifty $\mathrm{kg}$ of soil 108 was collected from a typical cultivated field where the main tillage practice is wheat dry farming

109 in Miandorood region, in the range of $36^{\circ} 33^{\prime}$ to $36^{\circ} 35^{\prime}$ latitude and $53^{\circ} 10^{\prime}$ to $53^{\circ} 13^{\prime}$ longitude 110 close to Sari (the capital of Mazandaran province) from a surface soil to a depth of $0-20 \mathrm{~cm}$, 111 following the recommendations of Angulo-Martinez et al. (2012) for laboratory experiments. 112 Samples were transported to the laboratory and sieved using a $2 \mathrm{~mm}$ sieve. They were then dried 113 in an oven at $105^{\circ} \mathrm{C}$ for 24 hours before rainfall simulations (Mohammadi and Kavian et al. 2015), 114 in order conserve the same moisture conditions in all samples.

115 Pedogenesis was generated on marl and unconsolidated sand deposits of the Pliocene. In general 116 slopes are gentle; lower than $10 \%$. The soil is characterized by a loam texture (with silt, sand and 117 clay components as $48.6 \%, 33.8 \%$ and $17.6 \%$, respectively), a low organic matter content of $1.2 \%$, 118 electrical conductivity of $0.499 \mathrm{dsm}^{-1}$, calcium carbonate content of $29.3 \%$ and a pH value of 7.36. 119 After simulating the acid rain, organic matter and calcium carbonate of the soil were evaluated in 120 some samples. 


\section{$123 \quad$ 2.2. Rainfall simulator characteristics}

124 The rainfall simulator was mounted on a metal A- frame structure. The height can range from 2 to $1252.7 \mathrm{~m}$ depending on the purpose. The telescopic legs allow the height of the nozzles to be changed, 126 which regulates the rainfall intensity and kinetic energy. The rainfall simulator can be used on 127 rugged terrain as the telescopic legs allow levelling at any slope angle from 0 to $45^{\circ}$. Simulated 128 rainfall is produced with two movable Veejet 80100 nozzles (Pall et al., 1983; Blanquies et al., 129 2003; Chouksey et al., 2017) with a diameter of $4.5 \mathrm{~mm}$. Each nozzle is installed in a metal deposit 130 to collect and reuse the excess of rainfall (that is not sprayed on the plot), and then returned to the 131 pumping system. The rainfall simulator was used in the laboratory of the Sari Agricultural Sciences 132 and Natural Resources University. The distilled water is pumped to the nozzles by means of a 133 flexible hose with 15-mm diameter connected to an electric pump. The water pressure is monitored 134 by a barometer installed in the transfer hose that allows the pressure to be regulated between 0 and $135160 \mathrm{KPa}$ (Fig. 1). A control board was designed with a programming capability of ten precipitation 136 programs, to perform experiments with different rainfall characteristics. The control board can be 137 used to set the velocity fluctuation nozzles, the oscillation angle of nozzles from $0^{\circ}$ to $60^{\circ}$, and the 138 duration of each rainfall event from 1 min to 1 hour. The plot size is $0.5 * 1 \mathrm{~m}^{2}$ and 3 splash cups 139 are located in the plot (figure 2). Splash cups were adapted from Morgan's original design (Morgan, 140 1978). 
141 Soil splash rates in eleven different treatments of rainfall acidity with dry and saturated soils, at

142 three intensities of 40,60 and $80 \mathrm{mmh}^{-1}$, based on the average rainfall in three replicates, were

143 recorded (Table 1). A total of 99 samples were tested.

144 Figure 2 shows the schematic representation of splash cups considering Morgan's original design 145 to calibrate kinetic energy and rainfall intensity (Morgan, 1978). The rainfall simulator is able to 146 generate drops with a diameter from 0.2 to $9.9 \mathrm{~mm}$. The fall velocity varied from 0.8 to $9.2 \mathrm{~m} \mathrm{~s}^{-1}$ 147 for different diameter classes in the height of $0.5 \mathrm{~m}$ above the soil surface. The minimum and 148 maximum droplet sizes decreased by increasing the operating pressures from 20 to $80 \mathrm{kPa}$. The 149 drop diameter of the simulated rainfall is close to natural precipitation in the region of Miandorood 150 (Kavian et al., 2018).

151 Simulated acid rainfall contained sulfuric acid and nitric acid with a ratio of 2:1 using the volume152 concentration formula, which was simulated at three $\mathrm{pH}$ levels: 3.75, 4.25 and 5.25. These levels 153 were selected because they are to the most representative ranges found in several recent studies 154 with negative effects in agricultural or natural fields and buildings (Livingston, 2016; Du et al., 155 2017; Mahdikhani et al., 2018; Zeng et al., 2018). Moreover, rainfall simulations with non-acidic 156 rain $(\mathrm{pH}=7.53)$ was also conducted in order to compare acid rain with a control situation.

\subsection{Experimental procedure}

159 Soil samples were located in the splash cups under dry and saturated conditions, using firstly non160 acidic water and then acidic water with $\mathrm{pH}$ values of 3.75, 4.25 and 5.25. After 10 minutes of 161 simulated rainfall, the splashed soil particles inside the splash cups after each treatment and 162 intensity were separated in different containers at the end of the experiments. The yielded particles 
163 were air-dried for 24 hours (Kavian et al., 2014). After the extra water was drained, the remaining

164 sediment was transferred into suitable containers of specified weight and were dried in an oven at $165105^{\circ} \mathrm{C}$ for 24 hours, then weighted using a scale (Sutherland \& Zieglers, 1998).

166 Finally, the splash erosion rate was calculated using equation 1 (Qinjuan et al., 2008).

$167 \quad \mathrm{~s}=\frac{\mathrm{D}_{\mathrm{t} 2}-\mathrm{D}_{\mathrm{t} 1}}{\left(\mathrm{t}_{2}-\mathrm{t}_{1}\right) \mathrm{A}}$

$168 \mathrm{~S}=$ splash rate during the specified rainfall $\left(\mathrm{gm}^{-2}\right.$ minute $)$

$169 \mathrm{D}_{\mathrm{t} 1}=$ Soil weight before splash experiment $(\mathrm{g})$

$170 \quad D_{\mathrm{t} 2}=$ Soil weight after splash test $(\mathrm{g})$

$171 \Delta \mathrm{t}=\left(\mathrm{t}_{2}-\mathrm{t}_{1}\right)$ rainfall duration $(\mathrm{min})$

$172 \quad \mathrm{~A}=$ area of splash cup $\left(\mathrm{m}^{2}\right)$

173

174 2.4. Statistical Analysis

175 The normality of data was assessed using by Kolmogorov-Smirnov test at a significance level of 176 0.05. Comparison of means was carried out by one-way ANOVA and the interactive effects of the 177 factors were analysed using two-way ANOVA. Duncan's multiple range test was applied for 178 multiple mean comparisons at a significance level of 0.05. All statistical analyses were conducted 179 using SPSS 23.0 (IBM, USA). 


\subsection{Comparison of drop splash effects on soil loss under dry conditions}

183 Table 2 shows the results of one-way ANOVA of the different treatments at intensities of 40, 60

184 and $80 \mathrm{mmh}^{-1}$ for the dry soil. Significant differences for the different treatments for an intensity 185 of $40 \mathrm{mmh}^{-1}$ at a confidence interval of $95 \%$ and an intensity of $60 \mathrm{mmh}^{-1}$ at a confidence level of 186 99\% are obtained. However, no significant differences are found for splash results with an intensity 187 of $80 \mathrm{mmh}^{-1}$. Considering the significant difference between the treatments at $40 \mathrm{mmh}^{-1}$, Duncan's 188 multiple range test was performed to show the difference among treatments. Figure 3 shows total initial soil erosion results and Duncan's multiple range test for control plot and acidic rain simulation under dry soil conditions. The highest particle loss due to splash effect in all degrees of rainfall intensities are observed with the most acidic rain $(\mathrm{pH}=3.75)$, reaching maximum values of $16 \mathrm{~g} \mathrm{~m}^{-2} \mathrm{~min}^{-1}$. On the contrary, the lowest particle losses are obtained in the control plot, where non-acidic rain is used with values ranging from 3.8 to $8.1 \mathrm{~g} \mathrm{~m}^{-2} \mathrm{~min}^{-1}$. The results show for 40 $\mathrm{mm} \mathrm{h}^{-1}$ that the AR1DS treatment is different (a) from the other three treatments, classified in group b. For a rainfall intensity of $60 \mathrm{mmh}^{-1}$, the treatments are classified into three groups. The most acidic rain (AR1DS treatment) is in the first group (a) again. AR2DS and AR3DS appear in 197 the same group (b) giving similar particle loss results, and the control plot (NARDS) is in group c. Finally, for $80 \mathrm{~mm} \mathrm{~h}^{-1}$ of rainfall intensity, the highest and the lowest values for splash were observed in the most acidic rain (AR1DS). The results are very similar with no significant difference among treatments at this high rainfall intensity, which even without acid rainfall, is able

201 to contribute in bare soils to a high soil particle loss values (Beguería et al., 2015; Eldridge and 202 Greene, 1994). Therefore, under dry conditions, we demonstrated that a higher concentration of 203 acid rain is able to increase soil erosion rates. The low rates observed for the control plot and the lowest acidic rain $(\mathrm{pH}<5.25)$ could be due to the presence of calcium carbonate in our soil samples 
205 (25.3\%), which was functioning as a stabilizing factor for aggregate stability (Bakhshipour et al., 206 2016). Therefore, parent material such as limestones or marls can act as a driving factor if 207 carbonates are correctly transferred to soil horizons, as Cerdà (2002) showed in Mediterranean 208 areas. However, when acid rain occurs, the lime present into the soils is neutralized; subsequently, 209 soil particles can be more easily separated (Gratchev and Towhata, 2016).

\subsection{Comparison of drop splash effects on soil loss under saturated conditions}

212 Table 2 also shows the results of the ANOVA test for soils under saturated conditions for the

213 intensities of 40, 60 and $80 \mathrm{mmh}^{-1}$. For $40 \mathrm{mmh}^{-1}$, there were no significant differences, despite 214 the increasing trend in soil particle loss values of acid rainfall compared to non-acidic rain, though 215 an increasing trend with more acidic rainfall was recorded. A significant difference in soil particle 216 loss is found for treatments with rainfall intensities of 60 and $80 \mathrm{mmh}^{-1}$.

217 Average values of total soil particle losses are shown in figure 4. Under saturated soil conditions, 218 the smallest amount of soil particle loss was registered in the control plot, as also seen under dry 219 soil conditions. The highest peaks of soil loss were obtained for the most acidic rains $(\mathrm{pH}=3.75$ 220 and $\mathrm{pH}=4.25)$, reaching maximum average values of $40 \mathrm{~g} \mathrm{~m}^{-2} \mathrm{~min}^{-1}$. However, for the Duncan 221 test, the differences are not significant at $40 \mathrm{~mm} \mathrm{~h}^{-1}$, and only for $60 \mathrm{~mm} \mathrm{~h}^{-1}$ the most acidic rainfall 222 shows a significant difference (AR3SS3). However, for $80 \mathrm{~mm} \mathrm{~h}^{-1}$, a significant difference was 223 clearly seen among treatments, with the AR1SS1 treatment showing only slightly lower levels of 224 soil particle loss than the AR2SS2 treatment. These findings confirm the importance of previous 225 soil moisture in the plot. As other authors have found, saturated soils respond according to a 226 Hortonian model, where runoff is able to activate soil loss when soil is saturated (Gabarrón- 
227 Galeote et al., 2013; Imeson and Lavee, 1998). Therefore, it is very important to pay attention to

228 soil water content prior to performing the rainfall experiments, because this can impact loss rates

229 (Hébrard et al., 2006; Wei et al., 2007). Kanga (1999) argued that when rainfall droplets hit the

230 ground the soil particles are disintegrated, and then, due to the water content and their reduced

231 adhesion force, particles are returned from the surface by droplets and soil particle loss increases.

232 Our results confirm the contention that in arid and semiarid areas, soil water content is able to

233 determine initial soil erosion rates, and an increase in acidification of the rainfall may also enhance

234 these rates. This is an important finding which will affect many regions, particularly for calcareous

235 soils in Iran. The rapid growth of urbanization and the increase in population close to large and 236 industrial Iranian cities are increasing emissions of pollutants to the air (Fanni, 2006; Hafeznia et 237 al., 2017; Yousefi et al., 2017), therefore, rapid solutions need to be found in order to stop this 238 confirmed problem. As other researchers in Iran have found, there are other driving factors that 239 also enhance soil erosion such as wind, bare soils and extreme rainfall events (Samani et al., 2016). 240 This new factor, acidic rain, needs to be added to the list of potential drivers of soil erosion (Tarolli, 241 2016). Therefore, solutions or regulations to limit air pollution should be implemented in order to 242 minimize, or stop, this confirmed land degradation process (Hansen et al., 2013; Smith et al., 243 2008).

3. 3. Evaluation of the effects of non-acidic rainfall on acidified saturated soil at different rainfall intensities

247 The negative effects of acidic rain in calcareous soils are clear; however, in order to observe an 248 inverse effect, the influence of non-acidic rain on acidic soils, we also conducted rainfall 249 simulations on saturated soils at three different $\mathrm{pH}$ values, 3.75, 4.25, 5.25, with three different 
250 rainfall intensities $\left(40,60\right.$ and $\left.80 \mathrm{~mm} \mathrm{~h}^{-1}\right)$ but with non-acidic rain. Table 2 shows the results of 251 one-way ANOVA for each treatment. There is no significant difference between the mean splash 252 rate of NARSS, NARSS1, NARSS2, NARSS3 at intensities of 40 and $60 \mathrm{mmh}^{-1}$, but there is for $25380 \mathrm{mmh}^{-1}$ at the $99 \%$ confidence level. Figure 5 shows the comparison among each treatment at 254 three rainfall intensities $\left(40,60\right.$ and $\left.80 \mathrm{mmh}^{-1}\right)$ and $\mathrm{pH}$ levels using the Duncan's test at confidence 255 interval of $95 \%$. For a rainfall intensity of $40 \mathrm{~mm} \mathrm{~h}^{-1}$ and $60 \mathrm{~mm} \mathrm{~h}^{-1}$, there were no significant 256 differences among treatments, registering the highest soil particle loss $\left(17.1 \mathrm{~g} \mathrm{~m}^{-2} \mathrm{~min}^{-1}\right)$ in the 257 control plot and the lowest one $\left(10 \mathrm{~g} \mathrm{~m}^{-2} \mathrm{~min}^{-1}\right)$ for $\mathrm{pH}$ values of 5.25 . With a rainfall intensity of $25880 \mathrm{mmh}^{-1}$, the control plot (NARSS) shows significant differences from the other treatments. The 259 lowest soil particle loss was found for the $\mathrm{pH}$ value of $5.25\left(18.7 \mathrm{~g} \mathrm{~m}^{-2} \mathrm{~min}^{-1}\right)$ with maximum rates 260 in the control plot $\left(32.9 \mathrm{~g} \mathrm{~m}^{-2} \mathrm{~min}^{-1}\right)$. This study shows the impact of soil saturation on increasing 261 soil particle loss.

262 According to the comparison of means, the results showed that the lowest splash rate was attributed 263 to the NARDS treatment. When comparing the average splash rate at the intensities of 40, 60 and $26480 \mathrm{mmh}^{-1}$, it was observed that splash rate increases with increasing intensity, confirming the 265 findings of other studies (Gholami et al., 2016; Sadeghi et al., 2015); this means that with 266 increasing rainfall intensity, the erosion rate increases, which can be due to the fact that with 267 increasing rainfall intensity, the number of droplets that can hit the soil increases, and raindrops 268 can increase in size and as a result their mass and falling velocity increase, which leads to more 269 kinetic energy (Mohammadi and Kavian., 2015). The energy of the raindrops is a major factor in 270 the disintegration of soil aggregates (Valettea et al., 2006; Barry et al., 2010; Brodowski et al., 271 2013), which can have a great influence on the separation of soil aggregates and results in splash 272 erosion (Liu et al., 2016). 
273 Also, changes in soil organic matter under short term acidic rainfall are plausible. As we observed

274 in table 3, on dry and saturated soils, organic matter decreased after acidic rain from $1.24 \%$ to

$2750.97 \%$ and from $1.28 \%$ to $0.99 \%$, respectively. Thus, further research is needed to investigate the

276 loss of soil we are registering because of the dissolution of organic matter, but now over long-term

277 periods.

278

279 3.4. Challenges and further investigations

280 Over long-time periods, acid rain might degrade vegetation and modify microbial communities

281 (Ling et al., 2010; Wu et al., 2016), both of which could conceivably change erosivity over time

282 (Xiao et al., 2017). However, we acknowledge that in this research using rainfall simulations, this

283 plausible mechanism for long term changes in erosivity cannot explain the findings presented here.

284 Splash erosivity is largely a physical process (Jomaa et al., 2012) and all of the studied soils are

285 similar, so the only difference can be in the way acidity affects the characteristics of the rain, for

286 example, by greater density or lower surface tension generating larger drops. It is widely accepted

287 that the mechanism cannot operate through impacts of acidity on the soil, as splash erosion is

288 caused when the water hits the soil, before any effect of the greater acidity can take place.

289 Therefore, future research lines must be conducted in order to develop a plausible and empirically-

290 verifiable mechanism to assess: why acid in the rain would increase erosivity instantaneously when

291 applied to the same soils, and, the specific pedological mechanism; or, ii) density, surface tension,

292 droplet size (and any other physical characteristic that might be relevant) for the acid amended 293 waters. 


\section{CONCLUSIONS}

296 In this research, we tested the possible negative impact of acidic rain on initial soil erosion rates

297 in carbonate soils. Our research confirmed that the highest soil particle loss due to splash effect 298 across all rainfall intensities tested was observed with the most acidic rain $(\mathrm{pH}=3.75)$ with the 299 lowest particle loss rates in the control plot, where non-acidic rain was used. A similar pattern was 300 seen for saturated soils. However, for acidic saturated soils, but with non-acidic rain, the highest 301 soil particle loss was seen in the control plot for all rainfall intensities. We demonstrated the 302 negative impact of acidic rain on soils, which could be exacerbated by a concomitant increase in 303 rainfall intensity. The development of rapid solutions and regulation by governments and land 304 planners in necessary to reduce emissions of pollutants to the air, because rainfall erosivity may 305 drastically increase.

306 We propose that further research must be conducted in order to develop a plausible and 307 empirically-verifiable mechanism to assess why acid in the rain would increase erosivity 308 instantaneously when applied to the same soils, or which rainfall characteristic is modified and is 309 able to destroy soil aggregates.

\section{References}

313 Alizadeh Choobari, O., Bidokhti, A. A., Ghafarian, P., Najafi, M. S., 2016. Temporal and spatial 314 variations of particulate matter and gaseous pollutants in the urban area of Tehran. Atmospheric 315 Environment, 141, 443-453. https://doi.org/10.1016/j.atmosenv.2016.07.003

316 Angulo-Martinez, M., Beguería, S., Navas, A. and Machin, J., 2012. Splash erosion under natural 317 rainfall on three soil types in NE Spain. Geomorphology, 175, 38-44. 318 https://doi.org/10.1016/j.geomorph.2012.06.016 
Ashtari, F., Esmaeil, N., Mansourian, M., Poursafa, P., Mirmosayyeb, O., Barzegar, M., Pourgheisari, H., 2018. An 8-year study of people with multiple sclerosis in Isfahan, Iran: Association between environmental air pollutants and severity of disease. J. Neuroimmunol. https://doi.org/10.1016/j.jneuroim.2018.02.019

Atash, F., 2007. The deterioration of urban environments in developing countries: Mitigating the air pollution crisis in Tehran, Iran. Cities, 24(6), 399-409. https://doi.org/10.1016/j.cities.2007.04.001

Ayoubi, S., Mokhtari, J., Mosaddeghi, M. R. \& Zeraatpisheh, M. 2018. Erodibility of calcareous soils as influenced by land use and intrinsic soil properties in a semiarid region of central Iran. Environmental monitoring and assessment, 190, 192. https://doi.org/10.1007/s10661-018-6557-y

Bahrami Asl, F., Leili, M., Vaziri, Y., Salahshour Arian, S., Cristaldi, A., Oliveri Conti, G., Ferrante, M., 2018. Health impacts quantification of ambient air pollutants using AirQ model approach in Hamadan, Iran. Environ. Res. 161, 114-121. https://doi.org/10.1016/j.envres.2017.10.050

Bakhshipour, Z., Asadi, A., Huat, B. B., Sridharan, A., Kawasaki, S., 2016. Effect of acid rain on geotechnical properties of residual soils. Soils and Foundations, 56(6), 1008-1020.

Barry, D. A., Sander, G. C., Jomaa, S., Heng, B. C. P., Parlange, J. Y., Lisle, I. G., Hogarth, W. L., 2010. Exact solutions of the Hairsine-Rose precipitation-driven erosion model for a uniform $\begin{array}{llllll}\text { grain-sized } & \text { soil. Journal } & \text { of } & \text { Hydrology, } & \text { 389: }\end{array}$ https://doi.org/10.1016/j.jhydrol.2010.06.016

Beguería, S., Angulo-Martínez, M., Gaspar, L., Navas, A., 2015. Detachment of soil organic carbon by rainfall splash: Experimental assessment on three agricultural soils of Spain. Geoderma 245-246, 21-30. https://doi.org/10.1016/j.geoderma.2015.01.010

Blanquies, J., Scharff, M. and Hallock, B., 2003. The design and construction of a rainfall simulator. International Erosion Control Association (IECA), 34th Annual Conference and Expo., Las Vegas, Nevada, February 24-28, 2003.

Brodowski, R., 2013. Soil detachment caused by divided rain power from raindrop parts splashed downward on a sloping surface. Catena, 105, 52-61. https://doi.org/10.1016/j.catena.2013.01.006

Cerdà, A., 2002. The effect of season and parent material on water erosion on highly eroded soils in eastern Spain. J. Arid Environ. 52, 319-337. https://doi.org/10.1006/jare.2002.1009

Chouksey, A., Lambey, V., Nikam, B.R., Aggarwal, S.P., Dutta, S., 2017. Hydrological modelling using a rainfall simulator over an experimental hillslope plot. Hydrology, 4(1), 17. doi:10.3390/hydrology4010017

Driscoll C. T., Lawarence, C. B., Bulger, A. J., Butler, T. J., Cronan, C. S., Eager, C., Lambert, K. F., Likens, G. E., Stoddard, J. L., Weathers K. C., 2001. Acidic deposition in the northeastern US: sources and inputs, ecosystems effects and management strategies. Bioscience, 51, 180-198. 
Du E, Dong D, Zeng X, Sun Z, Jiang X, de Vries W. 2017. Direct effect of acid rain on leaf chlorophyll content of terrestrial plants in China. Science of The Total Environment 605-606: 764-769 DOI: 10.1016/j.scitotenv.2017.06.044

Eldridge, D.J., Greene, R.S.B., 1994. Assessment of sediment yield by splash erosion on a semiarid soil with varying cryptogam cover. J. Arid Environ. 26, 221-232. https://doi.org/10.1006/jare.1994.1025

Ellison, W. D., 1944. Studies of Raindrop Erosion. Agriculture Engineering, 25, 181-182.

Ellison, W. D., 1947. Soil Erosion. Soil Science Society of America, 12, 479-484.

Fanni, Z., 2006. Cities and urbanization in Iran after the Islamic revolution. Cities, Urbanization and the Iranian Revolution 23, 407-411. https://doi.org/10.1016/j.cities.2006.08.003

Ferenbaugh, R. W., 1976. Effect of simulated acid rain on Phaseolus vulgaris L. American .Journal of Botany, 63, 283-288.

Fernández-Raga, M., Palencia, C., Keesstra, S., Jordán, A., Fraile, R., Angulo-Martínez, M., Cerdà, A., 2017. Splash erosion: A review with unanswered questions. Earth-Sci. Rev. 171, 463477. https://doi.org/10.1016/j.earscirev.2017.06.009

Free, G., 1952. Soil Movement by Raindrops. Agriculture Engineering, 33, 491-494, 496.

Gholami, L., Khaledi Darvishan, A., Kavian, A., 2016. Wood chips as soil conservation in field conditions. Arabian Journal of Geosciences, 9, 729. https://doi.org/10.1007/s12517-016-2731-0

Gratchev, I., Towhata, I., 2016. Compressibility of soils containing kaolinite in acidic environments. KSCE Journal of Civil Engineering, 20(2), 623-630. https://doi.org/10.1007/s12205-015-0141-6

Hafeznia, H., Pourfayaz, F., Maleki, A., 2017. An assessment of Iran's natural gas potential for transition toward low-carbon economy. Renew. Sustain. Energy Rev. 79, 71-81. https://doi.org/10.1016/j.rser.2017.05.042

Hansen, J., Kharecha, P., Sato, M., Masson-Delmotte, V., Ackerman, F., Beerling, D.J., Hearty, P.J., Hoegh-Guldberg, O., Hsu, S.-L., Parmesan, C., Rockstrom, J., Rohling, E.J., Sachs, J., Smith, P., Steffen, K., Susteren, L.V., Schuckmann, K. von, Zachos, J.C., 2013. Assessing "Dangerous Climate Change": Required Reduction of Carbon Emissions to Protect Young People, Future Generations and Nature. PLOS ONE 8, e81648. https://doi.org/10.1371/journal.pone.0081648

Hébrard, O., Voltz, M., Andrieux, P., Moussa, R., 2006. Spatio-temporal distribution of soil surface moisture in a heterogeneously farmed Mediterranean catchment. J. Hydrol. 329, 110-121. https://doi.org/10.1016/j.jhydrol.2006.02.012

Irving, P. M., 1987. Gaseous pollutant and acidic rain impact on crop in the United States: A comparision. Environmental Technology, 8, 451-458.

Iserloh, T., Ries, J.B., Cerdà, A. and Echeverría, M.T., Fister, W., Geissler, C., Kuhn, N.J., León, F.J., Peters, P., Schindewolf, M., Schmidt, J., Scholten, T., Seeger, M., 2013. Comparative 
measurements with seven rainfall simulators on uniform bare fallow land. Z. Für Geomorphol.

392 Suppl. 57, 11-26. DOI: 10.1127/0372-8854/2012/S-00085

393 Jomaa, S., Barry, D.A., Brovelli, A., Heng, B.C.P., Sander, G.C., Parlange, J.-Y., Rose, C.W., 394 2012. Rain splash soil erosion estimation in the presence of rock fragments. CATENA 92, 38-48. 395 https://doi.org/10.1016/j.catena.2011.11.008

396

397

398

399

400

401

402

403

404

405

406

407

408

409

410

411

412

413

414

415

416

417

418

419

420

421

422

423

424

425

Kavian, A., Azmoodeh, A., Solaimani, K., 2014. Deforestation effects on soil properties, runoff and erosion in northern Iran. Arabian Journal of Geosciences, 7(5), 1941-1950. https://doi.org/10.1007/s12517-013-0853-1

Kavian, A. A., Hayavi, F., Boroghani, M., 2015. The effect of polyacrylamide on the rate of splash erosion in different soils with using simulated rain. Journal of Range and Watershed Management, 67(2), 203-216. (In Persian).

Kavian A, Mohammadi M, Cerda A, Fallah M, Abdollahi Z. 2018. Simulated raindrop's characteristic measurements. A new approach of image processing tested under laboratory rainfall simulation. Catena 167: 190-197 DOI: 10.1016/j.catena.2018.04.034

Lelieveld, J., Evans, J.S., Fnais, M., Giannadaki, D., Pozzer, A., 2015. The contribution of outdoor air pollution sources to premature mortality on a global scale. Nature, 525 (7569), 367e371. doi:10.1038/nature15371

Ling, D.-J., Huang, Q.-C., Ouyang, Y., 2010. Impacts of simulated acid rain on soil enzyme activities in a latosol. Ecotoxicology and Environmental Safety 73, 1914-1918. https://doi.org/10.1016/j.ecoenv.2010.07.024

Liu, T., Luo, J., Zheng, Z., Li, T., He, S., 2016. Effects of rainfall intensity on splash erosion and its spatial distribution under maize canopy, Natural Hazards, 84, 233-247. https://doi.org/10.1007/s11069-016-2418-6

Livingston RA. 2016. Acid rain attack on outdoor sculpture in perspective. Atmospheric Environment 146: 332-345 DOI: 10.1016/j.atmosenv.2016.08.029

Mahdikhani M, Bamshad O, Fallah Shirvani M. 2018. Mechanical properties and durability of concrete specimens containing nano silica in sulfuric acid rain condition. Construction and Building Materials 167: 929-935 DOI: 10.1016/j.conbuildmat.2018.01.137

Manahan, S.E., 2005. Environmental Chemistry, CRC Press, 763p.

Marzen, M., Iserloh, T., Casper, M. C., Ries, J.B., 2015. Quantification of particle detachment by rain splash and wind-driven rain splash. Catena 127, 135-141. https://doi.org/10.1016/j.catena.2014.12.023

Mirhosseini, S, M. Shahabpour, J and Farpour, M, H. 2009. Geochemical Behavior of Zinc, Potassium and Sodium in Soils Affected by Acid Rains Related to Sar Cheshmeh Copper Smelter, Rafsanjan. Journal of Earth sciences, 18(71), 161-166.(In persian) 
Moarref, S., Sekhavatjoo, M. S., Hoseini Alhashemi, A. S., Takdastan, A., Malaei, A. R., 2011. Effectiveness of the quality of atmospheric precipitation in the face of pollutants in the air of Ahvaz city. Fifth National Conference and Specialized Exhibition of Environmental Engineering, 12 p.(In Persian)

Mohammadi, M. A., Kavian, A., 2015. Effects of rainfall patterns on runoff and soil erosion in field plots. International Soil and Water Conservation Research, 3(4), 273-281. https://doi.org/10.1016/j.iswcr.2015.10.001

Mohammadiha, A., Malakooti, H., Esfahanian, V., 2018. Development of reduction scenarios for criteria air pollutants emission in Tehran Traffic Sector, Iran. Sci. Total Environ. 622-623, 17-28. https://doi.org/10.1016/j.scitotenv.2017.11.312

Morgan, R. P. C., Mk, B., 1978. Field measurement of splash erosion. International Association of Scientific Hydrology Publication, 133, 373-382.

Neill, P.O., 1993. Environmental Chemistry. Chapman and Hall, 2nd edition, 268p.

Pall, R., Dickinson, W. T., Beals, D. McGirr, R., 1983. Development and calibration of a rainfall simulator. Canadian Agricultural Engineering, 25(2), 181-187.

Parsakhoo, A., Lotfalian, M., Kavian, A., Hosseini, S, A., Demir, M., 2012a. The effects of Rubus hyrcanus and Philonotis marchica (Hedw.) Brid. On soil loss prevention from cutslopes of a forest road. Journal of Forest Science, 58(8), 337-344.

Parsakhoo, A., Lotfalian, M., Kavian, A., Hosseini, S, A., Demir, M., 2012b. Calibration of a portable single nozzle rainfall simulator for soil erodibility study in hyrcanian forests. African Journal of Agricultural Research, 7(27), 3957-3963. https://doi.org/10.5897/AJAR12.202

Pell, E. J., Arny C. I., Pearson, N. S., 1987. Impact of simulated acid precipitation on quantity and quality of a field grown potato crop. Environ. Exp. Bot, 27, 6-14.

Purohit, S. S., Kakrani, B., 2002. Air Environment and Pollution. Agrobios (India) Publisher, $261 \mathrm{p}$.

Qinjuan, C., Qiangguo, C., Wenjun, M., 2008. Comparative study on rain splash erosion of representative soils in China, China Geography Science, 18 (2), 155-161. https://doi.org/10.1007/s11769-008-0155-9

Sadeghi, S. H. R., Gholami, L., Sharifi Moghadam, E., Khaledi Darvishan, A., 2015. Scale effect on runoff and soil loss control using rice straw mulch under laboratory conditions, Solid Earth, 6 , 1-8. https://doi.org/10.5194/se-6-1-2015

Sadeghi, S.H., Kiani Harchegani, M., Asadi, H., 2017. Variability of particle size distributions of upward/downward splashed materials in different rainfall intensities and slopes. Geoderma 290, 100-106. https://doi.org/10.1016/j.geoderma.2016.12.007 
Safari, A., Kavian, A., Parsakhoo, A., Saleh, I., \& Jordán, A. (2016). Impact of different parts of skid trails on runoff and soil erosion in the Hyrcanian forest (northern Iran). Geoderma, 263, 161167. https://doi.org/10.1016/j.geoderma.2015.09.010

Saleh, I., Kavian, A., Habibnejad Roushan, M., Jafarian, Z., 2017. The efficiency of vegetative buffer strips in runoff quality and quantity control. International Journal of Environmental Science and Technology, Article in press. https://doi.org/10.1007/s13762-017-1411-2

Samani, A.N., Khosravi, H., Mesbahzadeh, T., Azarakhshi, M., Rahdari, M.R., 2016. Determination of sand dune characteristics through geomorphometry and wind data analysis in central Iran (Kashan Erg). Arab. J. Geosci. 9, 716. https://doi.org/10.1007/s12517-016-2746-6

Shahbazi, H., Taghvaee, S., Hosseini, V., Afshin, H., 2016. A GIS based emission inventory development for Tehran. Urban Climate, 17, 216-229. https://doi.org/10.1016/j.uclim.2016.08.005

Smith, S. R., 1994. Effect of soil $\mathrm{pH}$ on availability to crops of metals in availability to crops of metals in sewage sludge-treated soils. II. Cadmium uptake by crops and implications for human dietary intake. Environmental pollution, 89 (1), 5-13. https://doi.org/10.1016/02697491(94)90003-5

Smith, P., Martino, D., Cai, Z., Gwary, D., Janzen, H., Kumar, P., McCarl, B., Ogle, S., O’Mara, F., Rice, C., Scholes, B., Sirotenko, O., Howden, M., McAllister, T., Pan, G., Romanenkov, V., Schneider, U., Towprayoon, S., Wattenbach, M., Smith, J., 2008. Greenhouse gas mitigation in agriculture. Philos. Trans. R. Soc. Lond. B Biol. Sci. 363, 789-813. https://doi.org/10.1098/rstb.2007.2184

Sutherland, R.A. and D. Ziegler. 1998. The influence on the soil conditioner "Agri-Sc" On splash detachment and aggregate stability. Soil and Till. Res. 45: 373-386. https://doi.org/10.1016/S09333630(97)00029-9

Tarolli, P., 2016. Humans and the Earth's surface. Earth Surf. Process. Landf. https://doi.org/10.1002/esp.4059

Uchiyama, R., Okochi, H., Ogata, H., Katsumi, N., Asai, D., Nakano, T., 2017. Geochemical and stable isotope characteristics of urban heavy rain in the downtown of Tokyo, Japan. Atmospheric Res. 194, 109-118. https://doi.org/10.1016/j.atmosres.2017.04.029

Ulrich, B., 1980. Production and consumption of hydrogen ions in the ecosphere. in: Hutchinson, T.C., Havas, M. (eds.) Effect of acid precipitation on terrestrial ecosystems. Plenum Press, New York, 222p.

Valettea, G., Prevosta, S., Lucasa, L., Leonard, J., 2006. SoDA project: A simulation of soil surface degradation by rainfall. Computers \& Graphics, 30, 494-506. https://doi.org/10.1016/j.cag.2006.03.016

Wang, Y., Xu, Y., Li, D., Tang, B., Man, S., Jia, Y., Xu, H., 2018. Vermicompost and biochar as bio-conditioners to immobilize heavy metal and improve soil fertility on cadmium contaminated 
soil under acid rain stress. Sci. Total Environ. 621, 1057-1065. https://doi.org/10.1016/j.scitotenv.2017.10.121

Wei, L., Zhang, B., Wang, M., 2007. Effects of antecedent soil moisture on runoff and soil erosion in alley cropping systems. Agric. Water Manag. 94, 54-62. https://doi.org/10.1016/j.agwat.2007.08.007

Wei, H., Liu, W., Zhang, J., Qin, Z., 2017. Effects of simulated acid rain on soil fauna community composition and their ecological niches. Environ. Pollut. 220, 460-468. https://doi.org/10.1016/j.envpol.2016.09.088

Welburn, A., 1990. Air pollution and acid rain: the biological impact. Longman Publications, pp.100-127.

Wu, J., Liang, G., Hui, D., Deng, Q., Xiong, X., Qiu, Q., Liu, J., Chu, G., Zhou, G., Zhang, D., 2016. Prolonged acid rain facilitates soil organic carbon accumulation in a mature forest in Southern China. Science of The Total Environment 544, 94-102. https://doi.org/10.1016/j.scitotenv.2015.11.025

Wuddivira, M. N., Stone, R. J. Ekwue, E. I., 2009. Clay, organic matter and wetting effects on splash detachment and aggregate breakdown under intense rainfall. Soil Science Society of American Journal, 73(1), 226-232. doi:10.2136/sssaj2008.0053

Xiao, H., Li, Z., Chang, X., Huang, J., Nie, X., Liu, C., Liu, L., Wang, D., Dong, Y., Jiang, J., 2017. Soil erosion-related dynamics of soil bacterial communities and microbial respiration. Applied Soil Ecology 119, 205-213. https://doi.org/10.1016/j.apsoil.2017.06.018

Xu, Z.J., Liu, G., Yu, J.D., Liu, W. 2002. Effects of acid rain on aggregate and its cemedins of red soil by simulated experiments. Journal of Soil and Water Conservation 16, 9-11.

Yokom, J. E., Bear, N. S., 1983. U.S. Environmental Protection Agency, EPA 600/8-83-016B, Washington, D.C. 6-1, 6-72.

Yousefi, G.R., Kaviri, S.M., Latify, M.A., Rahmati, I., 2017. Electricity industry restructuring in Iran. Energy Policy 108, 212-226. https://doi.org/10.1016/j.enpol.2017.05.018

Zeng X, Li Y, Ran Y, Yang K, Qu F, Wang P. 2018. Deterioration mechanism of CA mortar due to simulated acid rain. Construction and Building Materials 168: 1008-1015 DOI: 10.1016/j.conbuildmat.2018.03.033

Zhao, C., Ren, S., Zuo, Q., Wang, S., Zhou, Y., Liu, W., Liang, S., 2018. Effect of nanohydroxyapatite on cadmium leaching and environmental risks under simulated acid rain. Science of The Total Environment 627, 553-560. https://doi.org/10.1016/j.scitotenv.2018.01.267

Zheng, Z., Yu Hong, C., 1994. Electron microscope analyses of insoluble components in acid rain, Guilin City, China. Atmospheric Res. 32, 289-296. https://doi.org/10.1016/0169-8095(94)90066$\underline{3}$ 
